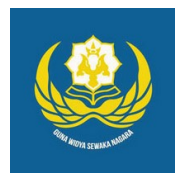

Jurnal Analogi Hukum

Journal Homepage: https://ejournal.warmadewa.ac.id/index.php/analogihukum

\title{
Sanksi Pidana Terhadap Pidana Penganiayaan yang Mengakibatkan Luka Berat
}

\author{
I Kadek Betit Pranata Suma*, I Wayan Rideng dan I Ketut Widia \\ Fakultas Hukum, Universitas Warmadewa, Denpasar, Bali-Indonesia \\ *betitkadek@gmail.com
}

How To Cite:

Suma, I. K. B. P., Rideng, I. W., \& Widia, I. K. (2021). Sanksi Pidana Terhadap Pidana Penganiayaan yang Mengakibatkan Luka Berat. Jurnal Analogi Hukum. 3 (2). 225-229. Doi: https://doi.org/10.22225/ah.3.2.2021.225-229

\begin{abstract}
The problem that often occurs in the community is persecution. Based on the decision issued by the Semarapura District Court Number: 67 / Pid.B / 20016 / PN.Srp A case of persecution has occurred. The formulation of the problem in this paper, namely: (1) How are the provisions for the Criminal Act of Persecution? (2) How do judges impose sanctions in the Crime of Persecution which results in serious injuries (case study of the Semarapura District Court Number: 67 / Pid.B /2016 / PN.Srp)? This study uses a normative legal research method, using the Law Approach, Case Approach, and Conceptual Approach. Source of Primary and Secondary Legal Materials. Document and literature study. By studying descriptively. Criminal action regulation itself has been included in the KUHP (Criminal Code) in CHAPTER XX. Based on the Judge's Decision Number: 67 / Pid.B / 2016 / PN.Srp, the defendant has been sentenced to 1 (one) year in prison. Before making a decision, the Panel of Judges made considerations from both juridical and psychological and sociological aspects.
\end{abstract}

Keywords: Persecution Relusting in Wounds.

\begin{abstract}
Abstrak-Permasalahan yang sering terjadi kalangan masyarakat yaitu mengenai penganiayaan. Berdasarkan Putusan yang dikeluarkan oleh Pengadilan Negeri Semarapura dengan Nomor: 67/Pid.B/20016/PN.Srp Sebuah kasus penganiayaan pernah terjadi. Adapun Rumusan Masalah yaitu: (1) Bagaimanakah pengaturan Sanksi Tindak Pidana Penganiayaan? (2) Bagaimana hakim memberikan sanksi dalam Tindak Pidana Penganiayaan yang berakibat luka berat (studi kasus Pengadilan Negeri Semarapura Nomor: 67/Pid.B/2016/PN.Srp)? Penelitian ini menggunakan metode penelitian hukum normative, dengan menggunakan Pendekatan Undangundang, Pendekatan Kasus, dan Pendekatan Konseptual. Sumber Bahan Hukum Primer dan Sekunder. Studi dokumen dan kepustakaan. Dengan mengkaji secara deskriptif. Pengaturan Tindak Pidana itu sendiri telah termuat dalam KUHP (Kitab Undang-undang Hukum Pidana) pada BAB XX. Berdasarkan Putusan Hakim dengan Nomor: 67/Pid.B/2016/PN.Srp terdakwa telah dijatuhi hukuman 1 (satu) tahun penjara. Dari segi aspek yuridis, aspek psikologis dan dari aspek sosiologis telah dipertimbang-timbangkan oleh Majelis Hakim saat akan menjatuhkan putusannya.
\end{abstract}

Kata Kunci: Penganiayaan Biasa berakibat luka-luka.

\section{Pendahuluan}

Permasalahan yang sering terjadi di kalangan masyarakat yaitu kejahatan seperti penganiayaan (Pettanase, 2017). Kejahatan penganiayaan terhadap tubuh menyebabkan timbulnya rasa sakit, luka bahkan dapat mengakibatkan kematian.

Kasus Penganiayaan yang mengakibatkan luka berat salah satunya pernah terjadi di Bali, tepatnya di pulai Bali bagian timur yaitu di Kabupaten Klungkung. Dengan No. Putusan 67/
Pid.B/2016/PN.Srp, sebuah kasus penganiayaan yang mengakibatkan 1 (Satu) orang korban yang telah dianiaya oleh seorang tersangka. Terdapat 1 (satu) bilah pedang yang digunakan tersangka, untuk melancarkan aksinya menganiaya korban.

Karena pada dasarnya, seperti yang kita ketahui Negara Indonesia adalah negara hukum (Anugrah, 2016), berikut adalah bunyi Pasal 1 Ayat (3) UUD 1945 yaitu amandemen ke-5 (lima), yang kemudian disahkan pada tahun 
2016. KUHP ( Kitab Undang - Undang Hukum Pidana ) adalah sumber hukum pidana materiil, yang memuat tentang aturan umum hukum pidana dan tindak pidana (Chazawi, 2002). Tindak pidana terdapat dalam bentuk hukuman / pidana yang termuat dalam pasal pasal KUHP, yaitu hukuman penjara, kurungan, dan denda (Prodjodikoro, 2003). Dalam suatu kejadian dapat dikatakan tindak pidana apabila terdapat faktor dalam diri pelaku maupun faktor luar dari diri pelaku, sehingga menjadikan pemicu adanya tindakan-tindakan yang melawan hukum. Apabila telah terjadi suatu tindak pidana yang mengharuskan pelaku untuk di pidana, maka hal tersebut telah dikategorikan sebagai suatu kejahatan. Kejahatan merupakan prilaku yang menyimpang terhadap etika dan moral. Suatu kejahatan sebagian besar membuat korbannya mengalami kerugian, dari segi materi, trauma yang berdampak pada psikis, maupun dari luka terhadap tubuh yang bersifat ringan maupun berat, yang dilakukan oleh pelaku terhadap korbannya.

Pasal 10 (sepuluh) telah menetapkan jenisjenis pidana yang diatur oleh dua pidana yaitu pidana pokok dan pidana tambahan. Pidana pokok terdiri atas empat jenis pidana, dan pidana tambahan terdiri atas tiga jenis pidana (Waluyo, 2014). Darimanapun tindak pidana itu dapat dipandang, tetap saja tidak dapat di toleransi lagi. Karena jika suatu kejadian sudah masuk ke ranah hukum tentu tetap tidak dapat dibenarkan. Namun kita harus tetap menyerahkan segalanya kepada hakim, sebab keyakinan hakim dalam memutus perkaranya tidak dapat diragukan lagi karena selain terikat oleh peraturan-peraturan tertentu, hakim juga harus menjunjung tinggi kebenaran dan keadilan. Hakim tidak boleh memutuskan suatu perkara dalam menyandarkan pelaku dalam suatu kasus. Ada atau tidaknya pemidanaan, atau bahkan berujung pada hanya sekedar pelanggaran yang mengharuskan pelanggarnya membayar denda, tentu semuanya kita serahkan kepada keputusan hakim.

Pengukuhan hukum dalam menetapkan jenis tindak pidana sebuah kasus penganiayaan menjadi hal penting, sebab hal ini pengukuhan HAM (Hak Asasi Manusia ). Sehingga penulis menarik suatu kesimpulan dan tertarik mengangkat judul penulisan yaitu "SANKSI PIDANA TERHADAP PENGANIAYAAN YANG MENGAKIBATKAN LUKA BERAT (Studi Kasus Putusan Nomor 67/Pid.B/2016/ PN.Srp)".

Rumusan Masalah dalam penelitian ini adalah Bagaimanakah pengaturan sanksi tindak pidana penganiayaan? Dan Bagaimana hakim memberikan sanksi dalam Tindak Pidana Penganiayaan yang berakibat luka berat (studi kasus Pengadilan Negeri Semarapura Nomor: 67/Pid.B/2016/PN.Srp)?

\section{Metode}

Berdasarkan tujuan pengkajian penelitian daripada perumusan masalah yang akan dilakukan oleh penulis yakni tipe penelitian yang akan digunakan dalam penulisan berupa pengkajian Hukum Normatif yaitu meneliti dengan menggunakan bahan pustaka, atau bahan sekunder. Dengan menggunakan Pendekatan Undang-undang (Statue Approach) yaitu bahan hukum yang mengacu terhadap Undang-undang yang berlaku, Pendekatan Kasus (Case Approach) yaitu pendekatan yang menggunakan prinsip keadilan untuk mencari nilai kebenaran dalam suatu kasus yang diangkat. dan Pendekatan Konseptual (Conseptual Approach) yaitu pendekatan yang melihat dari aspek konsep-konsep hukum yang melatarbelakangi suatu kasus, dan memberikan sudut pandang analisa penyelesaian permasalahandari nilai-nilai yang terkandung. Melalui bahan hukum primer serta sekunder dan juga bahan hukum tersier, yang akan menjadi bahan hukum inti untuk kajian penelitian ini. Untuk bahan hukum primer sendiri yaitu berupa Kitab Undang-undang Hukum Pidana (KUHP), Undang-undang Dasar Negara Republik Indonesia 1945, yakni mengenai Pasal 351 s/d 358 tentang Delik Penganiayaan yang diatur pada Bab XX. Selain Perundang-undangan, adapun bahan hukum primer lainnya berupa Putusan Pengadilan Negeri Semarapura No. 67/Pid.B/2016/PN.Srp. Kemudian bahan hukum sekunder ialah bahan hukum yang memiliki keterkaitan dengan masalah perlindungan hukum mengenai tindak pidana penganiayaan, melalui kajian kepustakaan seperti buku-buku, majalah, koran, internet. Dan yang terakhir adalah bahan hukum tersier seperti Kamus Besar Bahasa Indonesia (KBBI), ensiklopedia, dan sebagainya.

\section{Hasil dan Pembahasan}

\section{Pengaturan Sanksi Tindak Pidana Penganiayaan.}

Pengaturan Tindak Pidana Penganiayaan itu sendiri telah termuat dalam KUHP, yang berisi deretan-deretan Pasal 351 s/d 358 dengan pembagian sebagai berikut :

a. Penganiayaan biasa yang termuat pada Pasal 351.

Yaitu sebuah pasal yang mengatur tentang 
penganiayaan, yang dilakukan oleh seseorang dengan sengaja untuk mengakibatkan luka, rasa sakit. Namun tidak semua penganiayaan dapat dikatakan tindak pidana. Sebab, orang-orang yang telah memiliki perizinan seperti halnya dokter bedah yang harus menjalankan tugasnya mengobati pasien dengan cara melukai pasiennya.

\section{b. Penganiayaan ringan pada Pasal 352.}

Penganiayaan ringan yaitu penganiayaan yang menyebabkan luka ataupun penyakit dan membuat korbannya tidak dapat menjalani aktivitas sehari-hari diakibatkan karena cidera.

c. Penganiayaan berencana yang telah termuat didalam Pasal 353.

Penganiayaan berencana yaitu sebuah penganiayaan yang dilakukan oleh seseorang terhadap korbannya namun yang sebelumnya telah direncanakan oleh pelakunya.

d. Penganiayaan berat yang termuat pada Pasal 354.

Penganiayaan berat yaitu suatu tindak penganiayaan dengan unsur kesengajaan yang dilakukan oleh pelakunya sehingga membuat korbannya mengalami luka yang berat. Misalnya menusuk korbannya dengan pisau berulang kali.

e. Penganiayaan Berat Berencana yang telah termuat pada Pasal 355 .

Merupakan gabungan antara penganiayaan berat dan penganiayaan berencana.

f. Pasal 356 tentangpenganiayaan kekerasan di dalam rumah tangga.

Yaitu pasal yang mengatur tentang kejahatan yang dilakukan dari keluarga inti, akan tetapi terdapat Undang-Undang yang mengatur kejahatan kekerasan dalam rumah tangga yakni Undang-Undang Nomor 23 Tahun 2004 tentang penghapusan kekerasan dalam berumah tangga.

g. Kemudian Pasal 357 merupakan Pasal pencabutan hak berdasarkan Pasal 35 No. 1-4 dan Pasal 358 Kitab Undang - Undang Hukum Pidana yaitu Pasal yang mengatur tentang penyerangan secara berkelompok atau dapat disebut juga dengan meramai-ramai.

Sanksi Hukum oleh Hakim dalam Tindak Pidana Penganiayaan yang berakibat Luka Berat (Putusan Nomor: 67/Pid.B/2016/ PN.Srp). berikut:

Adapun Identitas Terdakwa yakni sebagai

Nama Lengkap : I Gede Agus Derry Pranata Als Zebro

Tempat, Tanggal Lahir : 02-Desember1995

Jenis Kelamin : Laki-Laki

Kebangsaan : Indonesia

Tempat Tinggal : Lingkungan Pegending, Kelurahan Semarapura Kauh, Kecamatan Klungkung, Kabupaten Klungkung.

D1

Agama : Hindu Pekerjaan : - Pendidikan :

Bahwa dengan keterangan dakwaan Jaksa Penuntut Umum sebagai berikut:

PRIMAIR:

Terdakwa I GEDE AGUS DERRY PRANATA Als. ZEBRO pada hari Sabtu tanggal 20 Agustus 2016 sekira pukul 22.30 WITA atau setidaknya pada bulan Agustus tahun 2016 bertempat di Lingkungan Pegending, Kelurahan Semarapura Kauh, Kecamatan Klungkung, Kabupaten melakukan Penganiayaan terhadap saksi korban I Komang Yuliawan.

Bahwa terdakwa dan saksi korban terlibat perkelahian namun berhasil dilerai, karena merasa tidak puas lalu terdakwa pergi kerumah kakek terdakwa untuk mengambil sebilah pedang bermata satu dengan panjang $70 \mathrm{~cm}$ dan langsung mengejar saksi korban yang berlari ke arah gang rumah saksi korban.

Bahwa selanjutnya saksi korban terjatuh di gang dalam posisi terlentang menghadap keatas, kemudian terdakwa datang membawa pedang dengan tangan kanannya dan langsung menebaskan ke arah tubuh saksi korban namun saksi korban berhasil menghindar lalu terdakwa kembali menebaskan pedangnya kearah saksi korban yang mengenai pada bagian lengan kiri bawah saksi korban sehingga mengakibatkan saksi korban mengalami luka dan dirawat inap di RSU Klungkung selama 4 (empat) hari untuk menjalani operasi sebagaimana Visum Et Repertum dengan Nomor: 445.04/40/CM yang ditangani dan ditandatangani oleh Dokter I Gede Dharma Satwika. Yaitu seorang Dokter pemeriksa pada Rumah Sakit Umum Daerah Pemerintah Kabupaten Klungkung dengan kesimpulan Os mengalami luka robek dan patah tulang di lengan bawah akibat benturan benda tajam. 
Perbuatan terdakwa sebagaimana diatur dan diancam pidana dalam Pasal 351 Ayat (2) KUHPidana

\section{SUBSIDAIR}

Bahwa taterdakwa I GEDE AGUS DERRY PRANATA Als. ZEBRO pada hari Sabtu tanggal 20 Agustus 2016 sekira pukul

22.30 Wita atau setidak-tidaknya pada suatu waktu dalam bulan Agustus tahun 2016 bertempat di Linkungan Pegending, Kelurahan Semarapura Kauh, kecamatan Klungkung, Kabupaten Klungkung atau setidak-tidaknya pada suatu tempat tertentu yang masih termasuk dalam Daerah Hukum Pengadilan Negeri Semarapura melakukan Penganiayaan terhadap I KomangYuliawan.

Selanjutnya saksi korban terjatuh di gang dalam posisi terlentang menghadap keatas, kemudian terdakwa dating membawa pedang dengan tangan kanannya dan langsung menebaskan kearah tubuh saksi korban namun saksi korban berhasil menghindar lalu terdakwa Kembali menebaskan pedangnya kearah tubuh saksi korban yang mengenai pada bagian lengan kiri bawah saksi korban sehingga mengakibatkan saksi korban mengalami luka dan dirawat inap di RSU Klungkung selama 4 (empat) hari untuk menjalani operasi sebagaimana Visum Et Repertum Nomor : 445.04/40/CM dibuat dan ditandatangani oleh Dokter I Gede Dharma Satwika, pemeriksa di RSU Daerah Pemerintah Kabupaten Klungkung dengan kesimpulan OS mengalami luka robek dan patah tulang di lengan bawah akibat benturan benda tajam. Dalam Pasal 351 Ayat (1) KUHPidana terdakwa telah diancam pidana dengan Pasal tersebut.

Berdasarkan pertimbangan yang ada maka hakim mengadili:

1) Menyatakan terdakwa I Gede Agus Derry Pranata Alias Zebro telah terbukti sah dan meyakinkan bersalah melakukan sebuah

'tindak pidana

mengakibatkan luka berat'

sebagaimana dalam dakwaan primair;

2) Akan diberikan hukuman selama 7 (tujuh) bulan kedepan kepada terdakwa;

3) Menetapkan masa penahanan yang sudah dijalani oleh terdakwa semuanya dikurangkan dari pidana yang sudah ditetapkan;

4) Menetapkan supaya terdakwa tetap berada di dalam tahanan.
5) Menyatakan barang bukti berupa:

a) 1 (satu) buah celana pendek berwarna abu-abu bergaris Dikembalikan kepada yang berhak yaitu: I Gede Agus Derry Pranata.

b) 1 (satu) potong celana pendek warna cream merk Giardano yang berisi noda.

c) 1 (satu) baju baju kaos oblong bergaris merk Quiksilver berisi noda. Dikembalikan kepada yang berhak yaitu: I Komang Yuliawan.

d) 1 (satu) bilah pedang bermata satu dengan panjang $70 \mathrm{~cm}$ (tujuh puluh) centi meter yang berisi darah dimusnahkan.

e) Supaya terdakwa membayar biaya perkara sebesar Rp. 2.000,- (dua ribu rupiah).

Kemudian adalah keterangan analisis dari penulis, dapat dijabarkan sebagai berikut:

Untuk memberikan putusan yang dilakukan oleh seorang laki-laki dewasa yang melakukan tindak pidana penganiayaan terhadap seseorang yang masih kerabatnya sendiri. Pertimbangan yang bersifat yuridis dan non- yuridis adalah pertimbangan yang ditetapkan oleh hakim dalam menjatuhkan putusannya terhadap seseorang yang melakukan tindak pidana penganiayaan.

Sebuah putusan yang ditetapkan oleh Majelis Hakim mengenai perkara ini memberikan hukuman tetap selama 1 (satu) tahun penjara dan dipotong selama terdakwa berada di dalam tahanan. Penulis menganggap bahwa setidak-tidaknya sudah tepat mengingat terdakwa dengan segala sikap pertanggungjawabannya. Penulis menganggap hal ini telah adil dengan seadil-adilnya. Hakim juga telah mempertimbangkan melalui aspek non- yuridis dan mengarah terhadap tindak pidana ini, dan akibat dari perbuatan terdakwa.

\section{Simpulan}

Berdasarkan hasil penelitian dan pembahasan yang telah diuraikan diatas, maka Penulis menarik kesimpulan sebagai berikut:

Pengaturan sanksi Tindak Pidana Penganiayaan yang pada dasarnya telah di atur oleh Kitab Undang-undang Hukum Pidana yang biasa disingkat menjadi KUHP, yaitu terdapat pada BAB XX Pasal $351 \mathrm{~s} / \mathrm{d}$ 358. Begitu pula dengan pembagian unsur-unsur daripada akibat perbuatan itu sendiri.

Sanksi hukum oleh hakim dalam menjatuhkan putusan mengenai perkara berakibat luka berat dengan Nomor 67/ 
Pid.B/2016/PN.Srp, dengan terdakwa atas nama I Gede Agus Derry Pranata Als. Zebro, telah terbukti bersalah di persidangan. Terdakwa dijatuhi hukuman 1 (satu) tahun dengan dipotong selama masa tahanan yang telah ditetapkan oleh jaksa penuntut umum. Mengenai dakwaan Jaksa Penuntut Umum semua hal tersebut telah sesuai dan begitupun dengan fakta-fakta dalam persidangan, dan saksi-saksi, barang bukti juga hasil Visum et Repertum yang diajukan oleh Jaksa Penuntut Umum sebagai alat bukti.

\section{Daftar Pustaka}

Anugrah, T. (2016). UUD 1945 dan Amandemen Terlengkap, Cetakan Pertama, Jilid kedua. Jakarta: Anugrah.

Chazawi, A. (2002). Kejahatan Terhadap Tubuh dan Nyawa, Cetakan ke-2. Jakarta: PT. Raja Grafindo Persada.

Kitab Undang-Undang Hukum Pidana (KUHP).

Kitab Undang-Undang Hukum Pidana Pasal 351 s/d 358 tentang Delik Penganiayaan yang diatur pada Bab XX.

Pettanase, S. (2017) Kriminologi. Semarang: Pustaka Magister.

Prodjodikoro, W. (2010) Tindak-tindak Pidana Tertentu Di Indonesia. Bandung: PT Refika Cipta.

Undang-Undang Dasar Negara Republik Indonesia 1945.

Waluyo, B. (2014). Pidana Dan Pemidanaan. Jakarta: Sinar Grafika. 